\title{
PENGEMBANGAN MODEL PEMBELAJARAN PASSING BAWAH BOLAVOLI
}

\author{
Sujito \\ ${ }^{1}$ SMP Negeri 1 Rogojampi \\ Banyuwangi, Indonesia \\ e-mail: muhamadsujito@yahoo.co.id
}

\begin{abstract}
Abstrak
Penelitian ini bertujuan untuk mengembangkan model pembelajaran passing bawah bolavoli bagi siswa kelas VII di SMP Negeri 1 Rogojampi - Banyuwangi sehingga bisa membuat peserta didik lebih senang, aktif, kreatif, dan termotivasi untuk bermain bolavoli. Produk yang diharapkan adalah buku panduan model pembelajaran passing bawah bolavoli. Metode yang digunakan dalam penelitian ini adalah penelitian pengembangan dengan memodifikasi langkah-langkah penelitian yang sesuai dengan kondisi di lapangan. Pengumpulan data dilakukan dengan menggunakan angket untuk ahli dan siswa. Dengan kualifikasi 2 pelatih bolavoli dan 1 guru pendidikan jasmani, dan untuk ujicoba digunakan kelompok kecil 10 siswa dan kelompok besar 15 siswa. Hasil yang diperoleh dari penelitian ini menyebutkan bahwa hasil evaluasi ketiga ahli adalah $90,22 \%$, sedangkan hasil evaluasi uji tahap I (uji kelompok kecil) dan uji tahap II (uji kelompok besar) adalah $83,33 \%$. Kesimpulan dari penelitian ini berdasarkan data yang dikumpulkan dari ahli bolavoli, ahli pembelajaran dan siswa saat uji coba tahap I dan ujicoba tahap II dan memperhatikan hasil analisa data yang telah dilakukan, maka semua model pembelajaran layak dan dapat digunakan.
\end{abstract}

Kata-kata kunci: pengembangan model pembelajaran, passing bawah, bolavoli

\begin{abstract}
This research aims to developing under passing volleyball leraning models for the students grade VII students Junior High School 1 Rogojampi - Banyuwangi so make the students more happy, active, creative, and motivated to play volleyball. The product is a guide book under passing volleyball learning models. The method used is reasearch and development $(R \& D)$ by modifying teps that are appropriate to the conditions in the field. Data collection using by a questionnaire for experts and students with the qualifications of 2 volleyball coaches and 1 physical education teacher, and for preliminary field test used 10 students and main field test used15 students. The results of research was obtained from the three experts is $90,22 \%$, the results of the preliminary field test and main field test is $83,33 \%$. The conclusion from this research is the under passing volleyball learning model is feasible to use.
\end{abstract}

Keyword: development of learning models, under passing, vollyball 


\section{PENDAHULUAN}

Pendidikan jasmani, olahraga, dan kesehatan (PJOK) merupakan media untuk mendorong pertumbuhan fisik, perkembangan psikis, keterampilan motorik, pengetahuan dan penalaran, penghayatan nilai-nilai (sikap-mentalemosional-sportivitas-spiritual-sosial), serta pembiasaan pola hidup sehat yang bermuara untuk merangsang pertumbuhan dan perkembangan kualitas fisik dan psikis yang seimbang

Pendidikan diselenggarakan dengan memberikan keteladanan, membangun kemauan, dan mengembangkan kreatifitas peserta didik dalam proses pembelajaran. Keberhasilan pendidikan sebagian besar ditentukan oleh guru yang mampu dan terampil mengelola proses belajar mengajar. Karena guru merupakan ujung tombak di dalam proses pembelajaran yang memiliki peran dan fungsi strategis dalam upaya mencapai tujuan pendidikan. Guru yang mampu dan terampil selalu meningkatkan pengetahuan dan keterampilan sejalan dengan kemajuan ilmu pengetahuan dan teknologi (IPTEK).

Guru PJOK memiliki peranan yang strategis dalam menyiapkan generasi bangsa dalam upaya meningkatkan pertumbuhan dan perkembangan jasmani dan rohani peserta didik. Oleh karena itu penyelenggaraan pembelajaran PJOK harus lebih dikembangkan ke arah yang lebih optimal sehingga peserta didik akan lebih inovatif, terampil, kreatif, memiliki pengetahuan dan pemahaman terhadap gerak manusia.

Pembelajaran di kelas VII terdapat materi mempraktikkan berbagai teknik dasar permainan dan olahraga, serta nilai-nilai yang terkandung di dalamnya termasuk permainan bolavoli. Dan yang kedua hasil pengamatan peneliti yang dilakukan di SMP Negeri 1 Rogojampi serta hasil wawancara dengan guru PJOK dan beberapa siswa SMP Negeri 1 Rogojampi, didapat beberapa kesimpulan di antaranya pembelajaran PJOK telah disampaikan oleh guru dengan berbagai materi yang sesuai dengan standar isi/silabus namun untuk materi permainan bolavoli kurang disukai oleh anak-anak siswa kelas VII SMP karena beberapa hal diantaranya: anak takut akan kerasnya bola dengan merasakan sakit bila bola menyentuh tangan, net terlalu tinggi sehingga anak tidak bisa leluasa menyeberangkan bola pada saat smash, lapangan terlalu luas hingga pada saat service bola tidak bisa melewati net, dan masih banyak faktorfaktor eksternal dan internal yang mempengaruhinya.

Di dalam proses pembelajaran sesungguhnya masih terlihat banyak siswa yang kurang aktif mingikuti pembelajaran pendidikan jasmani olahraga dan kesehatan khusunya materi bolavoli karena beberapa hal, antara lain: siswa malu karena merasa tidak bisa, siswa takut kena bola karena merasakan sakit, cuaca di lapangan yang panas karena terik matahari sehingga tujuan pembelajaran yang diharapkan tidak dapat tercapai dengan baik. Maka dari itu peneliti mengangkat masalah ini ke dalam sebuah penelitian pengembangan dengan maksud untuk menyusun buku pengembangan model pembelajaran bolavoli.

Menurut Sukmadinata (2005:164) penelitian dan pengembangan adalah "suatu proses atau langkah-langkah untuk mengembangkan suatu produk baru atau menyempurnakan produk yang telah ada, yang dapat dipertanggung jawabkan".

Menurut Winarno (2011:76) penelitian pengembangan merupakan "penelitian yang berupaya mengembangkan produk tertentu sesuai dengan kebutuhan masyarakat saat ini”. 
Berdasarkan beberapa kajian di atas maka dapat diambil pemahaman bahwa pengembangan adalah upaya yang dilakukan dengan langkah-langkah tertentu untuk mengembangkan suatu produk baru maupun penyempurnaan produk yang sudah ada.

Permainan bolavoli menurut Ngatiyono (2004:151) merupakan suatu permainan olahraga yang dimainkan oleh dua regu yang saling berhadapan dan tiap regu berjumlah enam orang,dimainkan dilapangan yang dipisahkan oleh net dengan cara melewatkan bola secara teratur melalui atas net sampai bola menyentuh lantai di daerah lawan. Bermain dan permainan adalah dua istilah yang sering dipakai secara bergantian di dunia olahraga.bermain merupakan bentuk kata kerja sedangkan permainan adalah kata benda. Siswa bermain bisa diartikan peserta didik melakukan suatu permainan, misalnya siswa bermain permainan bolavoli. Oleh karenanya dalam pembahasan teori-teori bermain yang ditemui di dalam berbagai kepustakaan, penggunaan kedua istilah ini sering pula digunakan bersama. Seperti contoh dalam bahasa Belanda yang terdapat dalam bukunya Trisnowati Tamat dan Moekarto (2006:4.6) digunakan istilah "Spel En Spelen" dan dalam bahasa Inggris "Games and Play". Berbagai pernyataan yang menyebutkan bahwa bermain dan permainan harus dipahami oleh guru PJOK, karena pada kenyataannya permainan itu telah lama disenangi dan mempengaruhi kepribadian serta kehidupan manusia.

Permainan bolavoli merupakan suatu permainan yang kompleks yang tidak mudah dilakukan oleh setiap orang, dikarenakan dalam permainan bolavoli membutuhkan koordinasi yang benar-benar bisa diandalkan untuk melakukan semua gerakan yang ada dalam permainan bolavoli. Walaupun begitu permainan bolavoli sangat cepat berkembang dan merupakan salah satu cabang olahraga yang populer sekali di Indonesia setelah cabang olahraga sepakbola dan bulutangkis.

Di dalam buku yang diterbitkan oleh PP.PBVSI (1995:43) permainan bolavoli terdiri beberapa teknik dasar, yaitu: " (1) latihan teknik dasar passing bawah, service bawah dan passing atas,, (2) latihan mengumpan dan smash (3) latihan smash keras dan bola tip, (4) latihan penerimaan serve, (5) latihan teknik membendung, (6) latihan teknik sevice atas"

Begitu kompleksnya permainan bolavoli menuntut guru untuk mengembangkan pembelajaran bolavoli dengan cara yang menyenangkan. Untuk itu dalam penelitian ini akan dikembangkan model pembelajaran passing bawah bolavoli agar peserta didik lebih senang, aktif, kreatif, dan termotivasi untuk bermain bolavoli

\section{METODE PENELITIAN}

Pengembangan produk dalam penelitian pengembangan dilakukan berdasarkan data hasil analisis kebutuhan lapangan. Data tersebut digunakan sebagai dasar dalam menyusun rencana pengembangan. Langkah-langkah pengembangan produk dalam penelitian pengembangan (research and development) yang dikembangkan oleh Borg \& Gall dalam Winarno (2011:77) adalah sebagai berikut: (1) Penelitian dan pengumpulan informasi dalam melakukan analisis kebutuhan (need assesment) dengan cara meriview literatur, melakukan observasi kelas, melakukan studi pendahuluan, dll. (2) Perencanaan pengembangan dilakukan dengan menentukan tujuan, membatasi ruang lingkup, dan mempersiapkan rencana ujicoba dengan skala tertentu. (3) 
Pengembangan produk (persiapan penyusunan materi instruksional, buku, dan alat evaluasi). (4) Persiapan ujicoba kelompok kecil, 1-3 sekolah, menggunakan 6-12 subjek. (5) Revisi produk pertama berdasarkan ujicoba lapangan. (6) Ujicoba lapangan, 5-10 sekolah, menggunakan 30 - 100 subjek. (7) Revisi produk kedua berdasarkan uji hasil uji coba lapangan, (8) Ujicoba lapangan 10-30 sekolah menggunakan 40-200 subjek. (9) Revisi produk ketiga berdasarkan uji hasil uji coba lapangan. (10) Diseminasi dan implementasi”.

Pada pengembangan ini peneliti tidak memamakai 10 (sepuluh) langkah mengingat jumlah sekolah yang di teliti hanya satu sekolah, serta keterbatasan waktu dan dana yang dimiliki peneliti, oleh karena itu peneliti menyederhanakan langkah penelitian yang dilakukan menjadi 8 (delapan) langkah. Hal ini sesuai dengan pendapat Ardhana (2002:9) yang menyebutkan bahwa "setiap pengembang tentu saja dapat memilih dan menentukan langkah-langkah yang paling tepat bagi dirinya berdasarkan kondisi khusus yang dihadapinya dalam proses pengembangan". Dengan mengacu pendapat tersebut peneliti boleh melakukan modifikasi dari langkahlangkah yang di kenalnya berdasarkan pertimbangan-pertimbangan yang terbaik baginya.

Dari uraian tersebut dapat disimpulkan bahwa peneliti atau pengembang diperbolehkan menentukan langkah penelitian berdasarkan kondisi khusus yang dihadapi. Adapun langkahlangkah prosedural pengembangan produk tersebut dapat kami uraikan sebagaimana terdapat dalam bagan sebagai berikut.

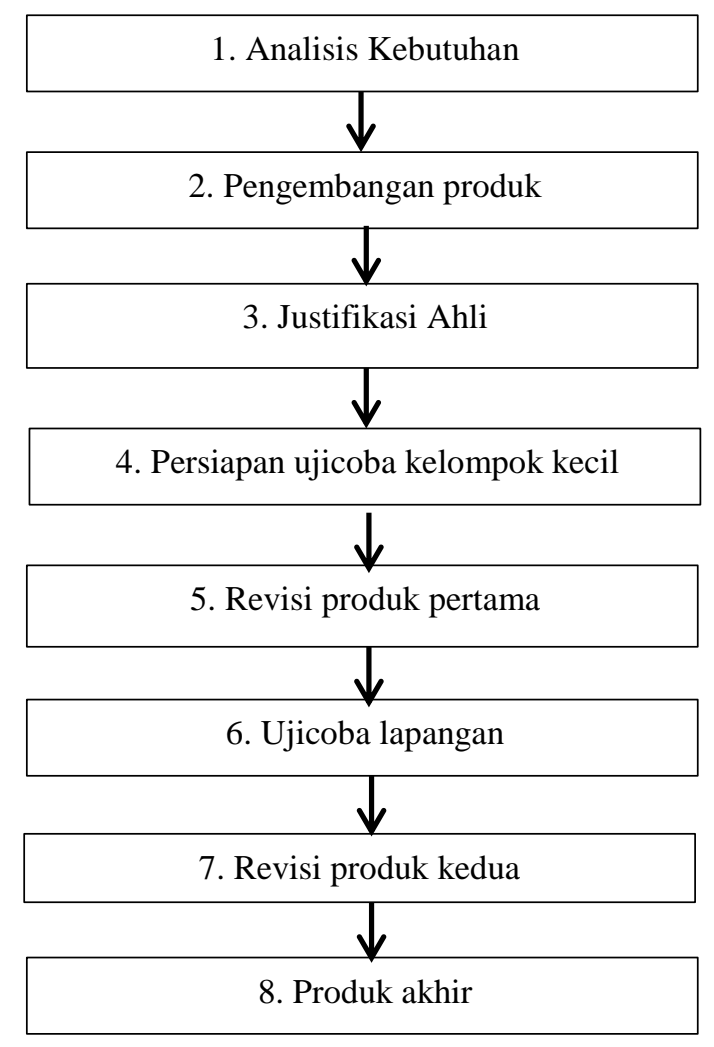

Gambar 1. Bagan Langkah-langkah prosedur pengembangan produk

Data yang digunakan untuk pengembangan model pembelajaran passing bawah bolavoli kelas VII dengan peraturan yang dimodifikasi ini adalah data kualitatif, karena data yang diperoleh dinyatakan dengan kalimat dan bukan dengan angka. Sedangkan data kuantitatif diperoleh dengan cara mengubah data kualitatif ke kuantitatif dengan jalan memberi skor pada data kualitatif tersebut. Instrumen yang digunakan dalam penelitian ini adalah dengan menggunakan angket, yang masing-masing angket terdiri 52 pertanyaan yang disebarkan kepada para ahli/pelatih bolavoli, guru penjasorkes (guru olahraga) dan siswa/peserta didik (yang terlibat dalam uji coba tahap I dan uji coba tahap II). Sebelum para ahli dan subyek uji coba mengisi angket untuk pengambilan data dijelaskan dahulu beberapa tata cara pengisian dari angket, seperti berikut. 
1. Sebelum mengisi instrumen ini dimohon terlebih dahulu untuk membaca petunjuk yang disediakan.

2. Mohon untuk membaca dan memahami buku panduan yang ada atau mengamati proses pembelajaran/latihan tehnik dasar passing bawah bolavoli yang dimodifikasi, kemudian mengisi lembar instrumen evaluasi yang telah disediakan dengan memberikan tanda silang (X) pada huruf a, b, c, atau d yang menurutnya sesuai.

3. Pedoman penilaiannya adalah sebagai berikut:

a. Jawaban a mempunyai nilai atau skor 4

b. Jawaban b mempunyai nilai atau skor 3

c. Jawaban c mempunyai nilai atau skor 2

d. Jawaban d mempunyai nilai atau skor 1

4. Saran-saran sebagai perbaikan mohon ditulis pada lembar/kolom yang telah disediakan.

\section{Analisis Data Kuantitatif}

Pada penelitian pengembangan ini teknik analisis data yang digunakan adalah teknik analisis deskriptif kuantitatif dengan persentase. Teknik ini digunakan untuk menganalisis data kuantitatif yang diperoleh dari hasil penyebaran angket. Rumus yang digunakan untuk menganalisis data adalah sebagai berikut:

Rumus untuk mengolah tanggapan ahli/pelatih bolavoli dan siswa/ pemain bolavoli.
1. Rumus untuk mengolah data per subyek uji coba menurut Sudjana (1990:44):

$$
P=\frac{x}{x i} \times 100 \%
$$

Keterangan:

$\mathrm{P} \quad=$ Persentase hasil evaluasi subyek uji coba

$\mathrm{X}=$ Jumlah jawaban skor oleh subyek uji coba

$\mathrm{Xi}=$ Jumlah jawaban maksimal dalam aspek penilaian oleh subyek uji coba

$100 \%=$ Konstanta

2. Rumus untuk mengolah data secara keseluruhan subyek uji coba menurut Sudjana (1990:44):

$$
P=\frac{\sum x}{\sum x i} \times 100 \%
$$

Keterangan:

$$
\begin{aligned}
\mathrm{P} & =\text { Persentase hasil } \\
& \text { keseluruhan } \\
& \text { evaluasi subyek uji coba } \\
\Sigma \mathrm{X} & =\begin{array}{l}
\text { Jumlah keseluruhan } \\
\text { jawaban subyek uji coba } \\
\text { dalam } \\
\text { keseluruhan aspek penilaian }
\end{array} \\
& =\text { Jumlah keseluruhan skor } \\
& \text { maksimal subyek uji coba } \\
\text { dalam keseluruhan aspek } & \\
\text { penilaian } & =\text { Konstanta }
\end{aligned}
$$

Untuk menentukan kesimpulan yang telah tercapai maka ditetapkan kriteria sebagaimana pada tabel 1 berikut. 
Tabel 1. Analisis Persentase Hasil Evaluasi Oleh Subyek Uji coba

PROSENTASE

KETERANGAN

MAKNA

\begin{tabular}{ccc}
\hline $80 \%-100 \%$ & Valid & Digunakan \\
\hline $60 \%-79 \%$ & Cukup Valid & Digunakan \\
\hline $50 \%-59 \%$ & Kurang Valid & Diganti \\
\hline$<50 \%$ & Tidak Valid & Diganti \\
\hline
\end{tabular}

(Sumber: Sudjana, 1990: 45)

\section{HASIL DAN PEMBAHASAN}

Hasil

Berikut ini peneliti akan menyajikan data hasil analisis kebutuhan, evaluasi ahli bolavoli, dan evaluasi kelompok uji coba tahap I (kelompok kecil) dan uji coba tahap II (kelompok besar), yang tertera pada tabel 2.

Tabel 2. Data Hasil Analisis Kebutuhan, Evaluasi Ahli Bolavoli, Uji Coba Tahap I (Kelompok Kecil) dan Uji Coba Tahap II (Kelompok Besar)

\begin{tabular}{|c|c|c|}
\hline No & Komponen & Temuan \\
\hline \multirow[t]{7}{*}{1.} & Analisis Kebutuhan & \\
\hline & a. Hasil pengamatan di & a. Banyak siswa kurang aktif. \\
\hline & lapangan tentang & b. Banyak siswa yang takut pada bola \\
\hline & kemampuan siswa & c. Ada siswa yang malu karena merasa tidak bisa bermain \\
\hline & $\begin{array}{l}\text { aram mengikut } \\
\text { pembelajaran pada }\end{array}$ & d. Siswa kurang menguasai teknik dasar bolavoli. \\
\hline & materi permainan & e. Ada sebagian kecil siswa yang sudah bisa passing bawah. \\
\hline & bolavoli. & $\begin{array}{l}\text { f. Guru banyak memberikan teori, tetapi sedikit memberi } \\
\text { contoh. }\end{array}$ \\
\hline \multirow{4}{*}{2.} & & g. Bola yang digunakan kurang mamadai jumlahnya bila \\
\hline & $\begin{array}{l}\text { Evaluasi Ahli } \\
\text { Hasil evaluasi ahli }\end{array}$ & dibanding dengan jumlah siswa yang belajar. \\
\hline & $\begin{array}{l}\text { Bolavoli }(n=3) \text {, dengan } \\
\text { jumlah instrumen } \\
\text { sebanyak } 52 \text { pertanyaan. }\end{array}$ & $\begin{array}{l}\text { a. Dari hasil evaluasi ketiga ahli bolavoli diperoleh persentase } \\
90,22 \% \text {, bahwa buku panduan/ materi tentang } \\
\text { pengembangan model pembelajaran passing bawah bolavoli } \\
\text { dapat digunakan di SMP Negeri } 1 \text { Rogojampi Banyuwangi. }\end{array}$ \\
\hline & & $\begin{array}{l}\text { b. Dari ahli bolavoli diperoleh saran/ masukan: } \\
\text { (1) Buku materi/panduan tentang pengembangan model } \\
\text { pembelajaran passing bawah hendaknya diberi sampul } \\
\text { bergambar yang berkaitan dengan materi passing bawah } \\
\text { bolavoli sehingga lebih menarik dan setiap model } \\
\text { pembelajaran supaya diberi foto/gambar bentuk kegiatannya. }\end{array}$ \\
\hline \multirow[t]{3}{*}{3.} & $\begin{array}{l}\text { Evaluasi Kelompok Uji } \\
\text { Coba }\end{array}$ & $\begin{array}{l}\text { Halaman pada beberapa lembar tidak nampak angkanya } \\
\text { supaya diteliti ulang. }\end{array}$ \\
\hline & $\begin{array}{l}\text { a. Hasil evaluasi uji coba } \\
\text { tahap I (kelompok }\end{array}$ & \\
\hline & $\begin{array}{l}\text { kecil) atau }(\mathrm{n}=10) \\
\text { dengan jumlah } \\
\text { instrumen sebanyak } 52 \\
\text { pertanyaan. }\end{array}$ & $\begin{array}{l}\text { Dari hasil evaluasi uji coba tahap I (kelompok kecil) } \\
\text { diperoleh jawaban } 85,10 \% \text { siswa menyatakan bahwa buku } \\
\text { panduan/materi tentang pengembangan model pembelajaran } \\
\text { passing bawah bolavoli dapat digunakan di SMP Negeri } 1 \\
\text { Rogojampi Banyuwangi. }\end{array}$ \\
\hline
\end{tabular}




\begin{tabular}{|c|c|c|}
\hline No & Komponen & Temuan \\
\hline & \multirow{2}{*}{$\begin{array}{l}\text { b. Hasil evaluasi uji coba } \\
\text { tahap II (kelompok } \\
\text { besar) atau (n=15), } \\
\text { dengan jumlah } \\
\text { instrumen sebanyak } 52 \\
\text { pertanyaan }\end{array}$} & $\begin{array}{l}\text { Masukan dari kelompok kecil yaitu : buku panduan/materi } \\
\text { supaya diberi sampul yang menarik dan diperbanyak } \\
\text { jumlahnya. }\end{array}$ \\
\hline & & $\begin{array}{l}\text { Dari hasil evaluasi uji coba tahap II (kelompok besar) } \\
\text { diperoleh jawaban } 81,57 \% \text { siswa menyatakan bahwa } \\
\text { buku panduan/materi tentang model pembelajaran passing } \\
\text { bawah bolavoli dapat digunakan di SMP Negeri } \\
\text { Rogojampi Banyuwangi. }\end{array}$ \\
\hline
\end{tabular}

Berdasarkan data hasil dari tabel 2 dapat dijelaskan tentang hasil pengamatan di lapangan tentang kemampuan siswa dalam mengikuti pembelajaran pada materi permainan bolavoli, hasil evaluasi ahli bolavoli $(\mathrm{n}=3)$, dengan jumlah instrumen sebanyak 52 pertanyaan, hasil evaluasi uji coba tahap I (kelompok kecil) atau $(n=10)$, dengan jumlah instrumen sebanyak 52 pertanyaan, evaluasi uji coba tahap II (kelompok besar) atau $(\mathrm{n}=15)$, dengan jumlah instrumen sebanyak 52 pertanyaan.

Dalam evaluasi ahli bolavoli yang terdiri dari 2 pelatih bolavoli dan 1 guru pendidikan jasmani terhadap rancangan produk pengembangan yang berupa model pembelajaran passing bawah bolavoli di SMP Negeri 1 Rogojampi Banyuwangi dengan jumlah instrumen untuk ahli bolavoli sebanyak 52 pertanyaan diperoleh data sebagaimana tertera pada tabel berikut:

Tabel 3. Data Hasil Dari Evaluasi Ahli Bolavoli (n=3), Jumlah Instrumen 52 Butki Pertanyaan

\begin{tabular}{lccccc}
\hline No & Ahli & $\begin{array}{c}\text { Skor } \\
\text { Minimal }\end{array}$ & $\begin{array}{c}\text { Skor } \\
\text { Maksimal }\end{array}$ & Skor Hasil & Persentase \\
\hline 1. & Ahli Bolavoli 1 & 52 & 208 & 187 & $89,90 \%$ \\
2. & Ahli Bolavoli 2 & 52 & 208 & 184 & $88,46 \%$ \\
3. & Ahli Bolavoli 3 & 52 & 208 & 192 & $92,31 \%$ \\
& Jumlah & 156 & 624 & 563 & $90,22 \%$ \\
\hline
\end{tabular}

Berdasarkan data hasil dari tabel 3 diketahui jumlah keseluruhan rata-rata persentase hasil evaluasi dari 3 ahli yang terdiri dari 2 ahli bolavoli dan 1 ahli pembelajaran adalah $\mathbf{9 0 , 2 2 \%}$ artinya memenuhi syarat klasifikasi valid $(80 \%$ $100 \%$ ) , sehingga produk ini dapat digunakan dalam pengembangan model pembelajaran passingbawah bolavoli di SMP Negeri 1 Rogojampi Banyuwangi.

Saran-saran ahli bolavoli terhadap hasil pengembangan model pembelajaran bolavoli di SMP Negeri 1 Rogojampi Banyuwangi adalah sebagai berikut:

1. Model pembelajaran sudah bagus, agar lebih menarik dan menyenangkan bagi peserta didik buatlah bentuk model pembelajaran yang membuat siswa lebih aktif bergerak.

2. Pelaksanaan model pembelajaran hendaknya disesuaikan dengan kondisi fisik dan kemampuan siswa, dengan cara membentuk kelompok yang sesuai dengan kondisi dan 
kamampuan siswa.

3. Model pembelajaran sudah bagus, dalam melakukan pembelajaran sudah memperhatikan faktor keamanan dan kenyamanan peserta didik, dengan memberikan model pembelajaran dari yang mudah menuju ke yang sulit.

\section{Evaluasi Uji Coba Kelompok Kecil dan Uji Coba Kelompok Besar}

Dalam evaluasi kelompok uji coba tahap I (kelompok kecil) dan uji coba tahap II (kelompok besar) terhadap produk pengembangan yang berupa model pembelajaran passing bawah bolavoli di SMP Negeri 1 Rogojampi Banyuwangi dengan jumlah instrumen untuk uji coba tahap I (kelompok kecil) dan uji coba tahap II (kelompok besar) masing-masing sebanyak 52 pertanyaan, dengan jumlah subyek 10 pemain pada uji coba tahap I (kelompok kecil) dan 15 pemain pada uji coba tahap II (kelompok besar).

Tabel 4. Data Hasil Kelompok Uji Coba Tahap I (Kelompok Kecil)

\begin{tabular}{cccccc}
\hline No & Aspek & $\begin{array}{c}\text { Skor } \\
\text { Minimal }\end{array}$ & $\begin{array}{c}\text { Skor } \\
\text { Maksimal }\end{array}$ & $\begin{array}{c}\text { Skor } \\
\text { Hasil }\end{array}$ & Persentase \\
\hline 1 & $\begin{array}{c}\text { Uji kelompok tahap I }(\mathrm{n}=10) \\
\text { dengan jumlah instrumen 52 }\end{array}$ & 520 & 2080 & 1770 & $85,10 \%$ \\
\hline
\end{tabular}

Berdasarkan data hasil dari tabel 4. diketahui jumlah keseluruhan rata-rata persentase hasil evaluasi uji coba tahap I (kelompok kecil) adalah $\mathbf{8 5 , 1 0 \%}$ artinya memenuhi syarat klasifikasi valid (80\% -
$100 \%$ ), sehingga produk ini dapat digunakan dalam pengembangan model pembelajaran passing bawah bolavoli di SMP Negeri 1 Rogojampi Banyuwangi.

Tabel 5. Data Hasil Kelompok Uji Coba Tahap II (Kelompok Besar)

\begin{tabular}{cccccc}
\hline No & Aspek & $\begin{array}{c}\text { Skor } \\
\text { Minimal }\end{array}$ & $\begin{array}{c}\text { Skor } \\
\text { Maksimal }\end{array}$ & $\begin{array}{c}\text { Skor } \\
\text { Hasil }\end{array}$ & Persentase \\
\hline 1 & $\begin{array}{l}\text { Uji kelompok tahap II } \\
(\mathrm{n}=15) \text { dengan jumlah } \\
\text { instrumen 52 butir }\end{array}$ & 780 & 3120 & 2545 & $81,57 \%$ \\
\hline
\end{tabular}

Berdasarkan data hasil dari tabel 5 diketahui jumlah keseluruhan rata-rata persentase hasil evaluasi uji coba tahap II (kelompok besar) adalah $\mathbf{8 1 , 5 7 \%}$ artinya memenuhi syarat klasifikasi valid
(80\% - 100\%), sehingga produk ini dapat digunakan dalam pengembangan model pembelajaran passing bawah bolavoli di SMP Negeri 1 Rogojampi Banyuwangi 
Tabel 6. Data Hasil Keseluruhan Kelompok Uji Coba Tahap I (Kelompok Kecil) dan Uji Coba Tahap II (Kelompok Besar)

\begin{tabular}{cccccc}
\hline No & Aspek & $\begin{array}{c}\text { Skor } \\
\text { Minimal }\end{array}$ & $\begin{array}{c}\text { Skor } \\
\text { Maksimal }\end{array}$ & $\begin{array}{c}\text { Skor } \\
\text { Hasil }\end{array}$ & Persentase \\
\hline 1 & $\begin{array}{l}\text { Uji kelompok tahap I } \\
\text { (n=10) dengan jumlah } \\
\text { instrumen 52 butir }\end{array}$ & 520 & 2080 & 1770 & $85,10 \%$ \\
\hline 2 & $\begin{array}{l}\text { Uji kelompok tahap II } \\
\text { (n=15) dengan jumlah } \\
\text { instrumen 52 butir }\end{array}$ & 780 & 3120 & 2545 & $81,57 \%$ \\
\hline & 1300 & 5200 & 4315 & $83,33 \%$ \\
\hline
\end{tabular}

Berdasarkan data hasil dari tabel 6 diketahui jumlah keseluruhan rata-rata persentase hasil evaluasi uji coba tahap I (kelompok kecil) dan uji coba tahap II (kelompok besar) adalah $\mathbf{8 3 , 3 3 \%}$ artinya memenuhi syarat klasifikasi valid $(80 \%$ $100 \%)$, sehingga produk ini dapat digunakan dalam pengembangan model pembelajaran passing bawah bolavoli di SMP Negeri 1 Rogojampi Banyuwangi.

Adapun hasil penelitian pengembangan ini berupa produk yang mempunyai spesifikasi produk sebagai berikut:

1. Buku dengan judul model pembelajaran passing bawah bolavoli bagi siswa kelas VII di SMP Negeri 1 Rogojampi Banyuwangi dengan ukuran kertas $16,5 \times 21 \mathrm{~cm}, 80$ gram dalam bentuk Booklet.

2. Buku terdiri empat bab, 56 halaman dengan 13 model pembelajaran bolavoli yang terdapat pada bab tiga.

3. Pendekatan yang terdapat dalam buku ini menggunakan teknik pembelajaran dari yang mudah ke yang sulit disertai dengan game menggunakan peraturan yang sederhana

\section{SIMPULAN DAN SARAN}

Berdasarkan tanggapan dan data yang dikumpulkan dari ahli bolavoli, ahli pembelajaran dan pemain bolavoli SMP
Negeri 1 Rogojampi Banyuwangi saat uji coba tahap I dan ujicoba tahap II dan memperhatikan hasil analisa data yang telah dilakukan, maka semua model pembelajaran valid dan dapat digunakan. Sehingga produk akhir pengembangan ini dengan spesifikasi produk:

1. Buku dengan judul model pembelajaran passing bawah bolavoli bagi siswa kelas VII di SMP Negeri 1 Rogojampi Banyuwangi dengan ukuran kertas $16,5 \times 21 \mathrm{~cm}, 80$ gram dalam bentuk Booklet.

2. Buku terdiri empat bab, 56 halaman dengan 13 model pembelajaran bolavoli yang terdapat pada bab tiga.

3. Pendekatan yang terdapat dalam buku ini menggunakan teknik pembelajaran dari yang mudah ke yang sulit disertai dengan game menggunakan peraturan yang sederhana

Dapat digunakan sebagai model pembelajaran passing bawah bolavoli di SMP Negeri 1 Rogojampi Banyuwangi.

\section{DAFTAR PUSTAKA}
Akbar Sa'dun. 2006. Dasar - dasar Teori Pengembangan Pembelajaran:..

$\begin{array}{rrr}\text { Ardhana,2002. } & \text { Metode } & \text { Penelitian } \\ \text { Pendidikan. } & \text { Jakarta: } & \text { Proyek }\end{array}$ 
Pengembangan Lembaga Pendidikan

Depdiknas. 2005. Pembelajaran Aspek Permainan dan Olahraga Bolavoli. Jakarta: Direktorat Jendral Pendidikan Dasar dan Menengah, Depdiknas

Depdikas. 2004. Undang - Undang Nomor 20 Tahun 2003 . Bandung : Fokus Media

Joyce. B dan Weil.M. 2000. Models of Teaching. Boston: Allyn and Bacon

Ngatiyono . 2004. Pendidikan Jasmani. Solo : Tiga Serangkai.

PBVSI, 1995. Pelatihan Bola voli. Jakarta : PP PBVSI

Sudjana, N. 1990. Penelitian Hasil Proses Belajar Mengajar. Bandung: Remaja Rosaa Karya.

Suherman Adang. 2001. Assesmen Belajar Dalam Pendidikan Jasmani. Jakarta: Depdiknas.
Sukmadinata. N.S. 2005. Metode Penelitian Pendidikan. Bandung: Remaja Rosda Karya

Tamat Trisnowati \& Moekarto, 2006, Pendidkan Jasmani dan Kesehatan, Universitas Terbuka, Jakarta.

Toto Subroto \& Yunyun Yudiana, 2010, Modul Permainan Bolavoli, FPOK Universitas Pendidikan Indonesia

Winarno, ME. 2011.Metodolgi Penelitian Dalam Pendidikan Jasmani. Malang : Media Cakrawala Utama Press

Winarno, ME. 2006. Dimensi Pembelajaran Pendidikan Jasmani.dan Olahraga, Malang : Universitas Negeri Malang

Winarno, ME. 2006. Perspektif Pendidikan Jasmani.dan Olahraga, Malang : Universitas Negeri Malang 